\title{
Faktor-Faktor yang Mempengaruhi Migrasi Sirkuler Pasien Kanker Payudara di Yogyakarta
}

\author{
Ratna Dewi ${ }^{1}$
}

\begin{abstract}
Abstrak
Migrasi penduduk merupakan salah satu upaya yang dilakukan untuk memenuhi kebutuhan hidup. Hal ini juga terjadi pada pasien kanker. Keterbatasan fasilitas kesehatan di daerah asal akan dapat mendorong mereka untuk mencari pengobatan di luar tempat tinggalnya. Penelitian ini bertujuan untuk mengetahui proses pengambilan keputusan untuk melakukan mobiitas pada pasien kanker yang melakukan pengobatan di yogyakarta. Hasil penelitian menunjukkan bahwa keterbatasan pelayanan kesehatan di daerah asal menyebabkan pasien melakukan pengobatan keluar daerahnya. Ada banyak pertimbangan bagi pasien kanker untuk mengambil keputusan melakukan migrasi. Pertimbangan dapat berupa pengaruh dari dalam maupun luar diri pasien. Kuatnya ikatan kekeluargaan membuat mereka berat meninggalkan daeraah asalnya. Proses pengambilan keputusan bukanlah hal yang mudah karena berkaitan dengan keluarga ataupun pekerjaan yang harus ditinggalkan. Pilihan daerah tujuan dipengaruhi oleh beberapa hal, antara lain jarak antara tempat tinggal dengan kota tujuan, informasi yang diterima mengenai daerah tujuan, dan penilaian pasien kanker terhadap daeah tujuan.
\end{abstract}

Kata-kata Kunci: migrasi sirkuler, kajian lokal Yogyakarta, social ekonomi

\begin{abstract}
People migration is an effort to fulfill their living needs. It was happened to the cancer patients. Limited facility of health services in one place can encourage people to get a healing outside the town of origin where the more complete facilities are available. The contrast in the services and facilities of health sector inter-regionally has become one of the matters encouring people to move to find far more complete health facilities. This research was aimed to determine the process of the decision-making of the cancer patient for treatment in Yogyakarta. This happened due to the limited cancer facilities and services in a number of hospitals. The result of the research shows that the limitation of health care facilities in the native region is one of the matters causing the patients to take medication outside their domicilies. There are many considerations to decide to move. Those considerations are the external and also internal effects. The strength of the kinship makes people are hard to leave their town of origin. The decision is not easy to be taken due to issues related to the family or the work which must be abandoned.In case of choosing the recovery place, there are some considerations on it, there are, the distance from the town of origin, the affection from the other people, and the condition or environment.
\end{abstract}

\section{Pendahuluan}

Migrasi atau perpindahan penduduk terjadi karena adanya perbedaan nilai kefaedahan suatu tempat, dimana tempat atau daerah tertentu mempunyai nilai yang lebih dalam memenuhi kebutuhan hidup seseorang. Sebagaimana Mantra (1999) menyebutkan bahwa penduduk akan berpindah dari daerah yang mempunyai nilai kefaedahan (place utility) yang rendah menuju daerah yang nilai kefaedahannya tinggi. Hal yang mendorong orang melakukan migrasi adalah faktor pemenuhan kebutuhan. Pada umumnya alasan orang melakukan migrasi adalah karena kebutuhan ekonomi. Meski sebenarnya masih

\footnotetext{
${ }^{1}$ Staf Pengajar Jurusan Sosiologi, FISIP, Universitas Jendral Soedirman.
} 
ada hal lain yang mendorong orang melakukan migrasi selain ekonomi, seperti misalnya kebutuhan sosial, psikologi, dan lain sebagainya. Kesehatan merupakan salah satu alasan atau motif yang mempengaruhi orang untuk melakukan migrasi (Taylor dalam Jackson, 1969) . Tindakan ini merupakan cara seseorang untuk memenuhi kebutuhan kesehatannya atau untuk penyembuhan penyakit.

Dalam mencapai tujuan tersebut, pilihan daerah juga dipengaruhi oleh nilai kefaedahan suatu daerah, yang memberi manfaat terpenuhinya kebutuhan kesehatan. Fasilitas kesehatan antar daerah yang tidak sama akan mendorong orang melakukan perpindahan atau migrasi. George (dalam Jansen, 1979) menyataka bahwa migrasi disebabkan oleh tersedianya kebutuhan di daerah tujuan.

Kanker merupakan penyakit yang bisa mematikan terutama jika terlambat penanganan atau tidak tuntas dalam pengobatan. Kanker itu sendiri merupakan hasil dari pembelahan sel yang mengalami pertumbuhan yang tidak normal dan tidak terkontrol, dan peningkatan jumlah sel abnormal ini pada umumnya membentuk benjolan yang disebut tumor atau kanker (Soebandri, 1996). Penyakit kanker menjadi salah satu penyebab kematian di dunia. Di Indonesia penyakit kanker menduduki peringkat ketiga penyebab kematian, dan 64\% penderitanya adalah perempuan, yang menderita kanker leher rahim dan kanker payudara (Anita, 2000). Sebenarnya kanker payudara tidak hanya menyerang perempuan saja, laki-laki pun dapat saja terkena penyakit ini,namun demikian jumlahnya sangat kecil Aryandono (2008). Chyntia (2009) menyebutkan bahwa penyakit kanker payudara merupakan penyakit yang umum menyerang kaum perempuan, meski demikian laki-laki pun memiliki kemungkinan mengalami penyakit ini dengan perbandingan 1 diantara 1000.

Kanker payudara merupakan penyakit dengan kasus terbanyak kedua setelah kanker leher rahim atau kanker serviks. Pada tahun 2007 kanker payudara menempati urutan pertama pasien rawat inap di seluruh rumah sakit di Indonesia sebesar 16,85\% dan disusul kanker leher rahim sebanyak 11,78\% (Profil Kesehatan Indonesia tahun 2008)

Yogyakarta sebagai salah satu propinsi di Indonesia, telah menjadi daerah tujuan bagi para migran baik permanen maupun sirkuler. Banyak faktor penarik dari daerah ini, seperti fasilitas pendidikan, tempat wisata, lapangan pekerjaan, dan lain sebagainya. Selain hal tersebut, di daerah ini ada bentuk migrasi yang dipengaruhi oleh faktor kesehatan. Individu yang di daerah asalnya, tidak terpenuhi kebutuhan kesehatannya, akan melakukan migrasi ke Yogyakarta yang fasilitas kesehatan lebih baik. RSUP Dr Sardjito menjadi salah satu rumah sakit rujukan bagi penderita kanker, terutama bagi mereka yang rumah 
sakit di daerah asalnya tidak memiliki peralatan lengkap dalam terapi penyembuhan kanker. Rumah sakit ini selain telah memiliki instalasi khusus untuk perawatan penyakit kanker, Instalasi Kanker Terpadu Tulip, juga merupakan salah satu rumah sakit yang melakukan program perawatan paliatif selain RS. Dr. Soetomo Surabaya, RS Cipto Mangunkusumo, RS Kanker Dharmais Jakarta, RS Wahidin Sudirohusoso Makasar, dan RS Sanglah Denpasar (www.rumahkanker.com). Perawatan paliatif merupakan perawatan kesehatan terpadu yang aktif dan menyeluruh, bertujuan untuk mengurangi penderitaan pasien, memperpanjang umurnya, meningkatkan kualitas hidupnya dan juga memberikan dukungan kepada keluarganya.

Penderita kanker, terutama yang berasal dari luar Yogyakarta, melakukan migrasi untuk memperoleh perawatan. Terapi pengobatan atau perawatan yang dilakukan dapat berupa perawatan lanjutan setelah mendapat "pertolongan pertama" dari rumah sakit di daerahnya, maupun memang perawatan dari awal ketika pertama kali memeriksakan diri. Namun demikian, migrasi yang dilakukan individu tidak hanya terjadi satu kali, tapi dapat berulang kali, karena individu tersebut harus melakukan terapi ataupun pemerikasaan secara berkala. Fasilitas atau penyediaan tempat tinggal, terutama di dekat rumah sakit, akan memudahkan mereka dalam melakukan migrasi.

Bentuk migrasi yang dilakukan oleh pasien kanker tentu menjadi berbeda dengan mereka yang melakukan migrasi karena dorongan ekonomi, misalnya. Mereka yang melakukan migrasi karena motif ekonomi terdorong menuju daerah yang akan dapat memberikan kesempatan untuk mendapatkan penghasilan atau uang yang lebih baik daripada di daerah asalnya. Mereka seperti mengejar dan mengumpulkan uang, sementara pada penduduk yang melakukan migrasi karena alasan kesehatan, justru sebaliknya, bukan mencari uang, namun justru "kehilangan" uang, dan bahkan peran sosial di daerah asalnya. Dari hal tersebut, permasalahan yang ingin dikaji adalah bagaimana proses pengambilan keputusan pada pasien kanker dalam melakukan migrasi sirkuler, serta faktor yang mempengaruhi pasien dalam memilih daerah tujuan.

\section{Kajian Teoritis}

Migrasi diartikan sebagai perpindahan penduduk dari suatu daerah menuju daerah lain dengan tujuan melewati batas wilayah administrasi tertentu (Mantra, 1985 ). Mantra membedakan migrasi menjadi migrasi permanen atau lebih sering disebut sebagai migrasi, dan migrasi non permanen yaitu perpindahan yang dilakukan tanpa adanya niat untuk menetap, yang lebih sering disebut dengan migrasi sirkuler. Terdapat banyak perbedaan ruang konsep migrasi. Hal ini terjadi karena perbedaan ruang lingkup yang digunakan terkait batas wilayah dan batas 
waktu. Menurut Badan Pusat Statistik yang masuk dalam kategori migrasi adalah seseorang yang melakukan perpindahan dari satu wilayah ke wilayah lain dengan batas propinsi dan batas waktu minimal enam bulan. Lee (2000) menyebutkan cakupan migrasi antara lain semua bentuk perpindahan akibat perubahan tempat tinggal yang bersifat permanen maupun semi permanen tanpa dibatasi jarak tempat pindah. Jika menggunakan batasan yang diberikan oleh BPS, maka secara statistik kondisi perpindahan penduduk cenderung rendah. Padahal sebenarnya masyarakat cenderung melakukan perpindahan, hanya saja tidak melewati batas propinsi dan kurang dari enam bulan, misalnya hanya melewati batas kabupaten atau desa. Perpindahan yang demikian merupakan perpindahan yang semi permanen atau sirkuler. Kemajuan dalam prasarana dan transportasi mendukung migrasi sirkuler ini. Selain banyak faktor lain yang mempengaruhi individu dalam mengambil keputusan untuk melakukan migrasi sirkuler. Migrasi yang dilakukan dalam rangka pengobatan yang dilakukan individu tidak hanya terjadi satu kali, tapi dapat berulang kali, karena individu tersebut harus melakukan terapi ataupun pemeriksaan secara berkala. Pasien kanker yang berasal dari luar daerah Yogyakarta akan datang ke tempat tersebut, tinggal sementara untuk waktu tertentu dan kembali ke daerah asalnya setelah terapi selesai. Dan akan kembali lagi untuk kepentingan yang sama.
Lee (2000) membagi faktor yang mempengaruhi orang dalam mengambil keputusan untuk melakukan mobiitas, yaitu faktor-faktor yang berada di daerah asal, faktor -faktor yang berada di daerah tujuan, rintangan antara, dan faktor pribadi atau individu. Di setiap daerah asal dan daerah tujuan terdapat faktor-faktor positif ,yaitu faktor yang menguntungkan dan faktor-faktor negatif yang memberikan nilai negatif pada suatu daerah. faktor-faktor positif yang ada di daerah asal akan membuat seseorang bertahan atau mengikat untuk tetap tinggal di daerahnya dan tidak melakukan migrasi. Faktor-faktor positif di daerah tujuan bersifat menarik seseorang untuk melakukan migrasi, karena terdapat faktor yang mampu memenuhi kebutuhan mereka. Bagi pasien kanker, tersedianya fasilitas kesehatan di daerah tujuan merupakan salah satu faktor positif yang bisa menarik mereka untuk melakukan perpindahan. Namun keluarga, pekerjaan, lingkungan sosial tempat tinggal mereka dapat menjadi faktor positif di daerah asal yang tentu saja akan menahan mereka untuk pergi meninggalkan daerahnya. Besar kecilnya arus migrasi dipengaruhi oleh rintangan antara seperti biaya,jarak, topografi antara daerah asal dan daerah tujuan, sarana transportasi. Pasien kanker dalam memilih daerah tujuan untuk melakukan pengobatan mempertimbangkan biaya yang harus dikeluarkan, baik biaya untuk melakukan perjalanan dari daearah asal menuju daerah tujuan, biaya hidup selama menetap di daerah 
tujuan untuk sementara, dan juga biaya untuk pengobatan. Jarak juga menjadi faktor rintangan atau penghalang antara. Pilihan daerah tujuan tentu dipengaruhi kondisi fisik dari pasien kanker. Kondisi tubuh yang lemah karena penyakit yang dideritanya, tentu akan mempertimbangkan kembali ketika akan melakukan migrasi ke daerah yang jaraknya jauh. Namun demikian, faktor dari dalam diri pasien kankerlah yang mempunyai pengaruh besar dalam pengambilan keputusan untuk melakukan suatu migrasi. Hal ini dipengaruhi oleh pengetahuan pasien kanker mengenai daerah tujuan seperti fasilitas kesehatan yang ada, kondisi masyarakat di lingkungan daerah tujuan. Pengetahuan ini dapat diperoleh pasien baik dari informasi melalui media maupun informasi dari kerabat, sahabat atau tetangga terutama mereka yang memang telah pernah menetap di daerah tersebut.

\section{Metode penelitian}

Penelitian dilakukan di RSUP Dr. Sardjito Yogyakarta, dengan pertimbangan bahwa di rumah sakit ini tersedia pelayanan dan fasilitas khusus bagi penderita kanker, yaitu Instalasi Kanker Terpadu "Tulip" dan merupan rumah sakit rujukan bagi daerah yang tidak memiliki fasilitas pelayanan penyakit kanker. Penelitian ini menggunakan pendekatan kualitatif deskriptif. Teknik pemilihan informan dilakukan dengan menggunakan teknik purposive, dengan memilah subjek penelitian ke dalam kategori yaitu pasien kanker payudara yang berasal dari luar Daerah Istimewa Yogyakarta, yang sedang pasien yang sedang menjalani masa kemoterapi dan atau pengobatan lain seperti radiasi, dan terutama adalah pasien yang berada dalam kondisi "sehat", dalam arti mereka mampu diajak berkomunikasi. Data yang diperlukan dalam penelitian ini berupa data primer dan data sekunder. Data primer diperoleh dengan wawancara mendalam (indepth interview) yang dipandu pedoman wawancara. Data sekunder diperoleh dengan menggunakan media pustaka, referensi yang berkaitan dengan tema penelitian serta menggunakan dokumen atau arsip dari Instalasi Kanker Terpadu Tulip RSUP Dr Sardjito. Teknik analisis data yang digunakan dalam penelitian ini adalah analisis kualitatif dengan model analisisnya adalah interaktif (Miles dan Huberman, 1992). Dalam model ini ada tiga komponen analisis yaitu reduksi data, sajian data dan penarikan kesimpulan (verifikasi). Verifikasinya dilakukan dalam bentuk interaktif dengan proses pengumpulan data sebagai suatu siklus.

\section{Pengambilan Keputusan Melakukan Migrasi}

Proses pengambilan keputusan untuk melakukan migrasi tidaklah selalu sama pada setiap individu, dan bukan suatu hal yang mudah. Ada sebagian yang begitu mudah untuk memutuskan melakukan perpindahan ke suatu daerah, namun sebagian yang lain akan begitu sulit. Banyak hal yang menjadi bahan 
pertimbangan sebelum seseorang memutuskan untuk melakukan perpindahan ke suatu tempat, yang bisa berasal dari dalam maupun luar diri pasien. Keinginan, dan harapan untuk sembuh dari penyakit yang ada pada diri pasien akan mendorong mereka melakukan migrasi untuk mencari pengobatan di luar daerahnya. Demikian pula dengan infomasi yang diterima mengenai kondisi daerah tujuan maupun informasi dari orang yang pernah melakukan pengobatan di daerah tersebut, menjadi bahan pertimbangan sebelum memutuskan untuk melakukan migrasi.

Pasien kanker akan mempertimbangkan keuntungan dan kerugian yang akan diperoleh (Taylor dalam Jackson, 1969), dimana terjadi suatu "diskusi" untuk memperdebatkan keuntungan dan kerugian yang akan diperoleh jika melakukan pengobatan keluar daerah. Pertimbangan keuntungan antara lain pengobatan yang lebih lengkap dan tuntas serta harapan kesembuhan yang lebih besar jika dibandingkan dengan tidak melakukan migrasi untuk berobat. Sedangkan kerugian ada pada biaya yang dikeluarkan ketika melakukan perjalanan, biaya hidup yang harus dikeluarkan selama beberapa hari, serta biaya yang tidak secara langsung hilang, yaitu hilangnya atau berkurangnya pendapatan dan kesempatan kerja, karena harus pergi meninggalkan lingkungan sosialnya.

Salah satu informan dari Temanggung menyatakan bahwa tidak hanya keluarga yang menjadi bahan pertimbangan, besarnya biaya yang harus dikeluarkan baik untuk perjalanan maupun pengobatan, serta jarak antara daerah tempat tinggal dan daerah tujuan juga berpengaruh dan menjadi bahan pertimbangan ketika memutuskan untuk melakukan migrasi dalam mencari pengobatan, berikut pernyataannya:

"Ya pake pertimbanganlah, kok jauh, nanti keluarga jadi repot, anak-anak bagaimana, ya mahal juga kalau jauh. Tapi saya pikir gimana lagi kalau memang obatnya adanya di sini (Sardjito)". (Ibu Wy).

Demikian pula dengan ibu TK dari Wonosobo yang mengaku sangat berat mengambil keputusan untuk migrasi karena harus meninggalkan keluarga dan pekerjaan di daerah asalnya, namun justru dari keluargalah ibu TK akhirnya bersedia memutuskan untuk melakukan migrasi dalam rangka memperoleh kesembuhan:

"Ya berat juga sih mau pergi meninggalkan rumah, anak-anak masih kecil, tapi kalau tidak ke sini, tidak diobati ya malah tambah parah. Jadi saya pikir lebih baik saya berobat ke sini biar sembuh, kan perginya cuma beberapa hari . Semua untuk keluarga. Kalau sudah selesai terapi kan sudah kumpul lagi (dengan keluarga)". (Ibu Tk).

Kuatnya ikatan kekeluargaan membuat pasien berat untuk meninggalkan daerah asalnya. Meninggalkan keluarga, pekerjaan dan tanggung jawab yang dimiliki di lingkungan sosialnya menjadi bahan pertimbangan untuk memutuskan melakukan migrasi. Keluarga merupakan salah satu faktor utama yang mempengaruhi keputusan seseorang untuk pergi meninggalkan daerahnya (Muhidin, 2002). Demikian dengan ibu Is dari Magelang yang berdiskusi terlebih 
dahulu dengan suami dan keluarga besarnya:

"Ya setelah mendapat penjelasan dari dokter di sana, saya rundingan dulu sama suami gimana baiknya. Selain dengan suami, juga minta saran dari keluarga besar yang lain karena kan saya juga masih harus ninggalin anak-anak kalau harus berobat keluar kota, soalnya waktu itu suami masih kerja di Kebumen. Untungnya keluarga besar mendukung, trus akhirnya ya sepakat untuk berangkat dan berobat ke Yogya saja, lagian untuk apa menyimpan penyakit”.(Ibu Is).

Pernyataan informan tersebut menyiratkan bahwa di daerah tempat tinggalnya tidak terdapat fasilitas yang lengkap untuk pengobatan kanker secara tuntas, baik dalam hal tenaga medis maupun peralatan. Hal inilah sebagaimana disebutkan oleh Lee (2000) bahwa memang faktor di daerah asal mendorong seseorang untuk meninggalkan tempat tinggalnya. Pada umumnya pasien kanker memperoleh mengetahui bahwa dirinya menderita kanker payudara, dan memperoleh pertolongan pertama di daerah asalnya. Namun terbatasnya fasilitas, baik dari sisi tenaga medis dimana tidak ada dokter spesialis onkologi atau kanker, maupun peralatan kesehatan, membuat mereka mau tidak mau akan melakukan migrasi. Sementara terdapat faktor-faktor di daerah tujuan, berupa fasilitas pelayanan kesehatan yang lebih lengkap yang akan menarik seseorang untuk melakukan migrasi ke tempat tersebut. Namun demikian, terbatasnya fasilitas di daerah asal tersebut, tidak berarti mereka akan mudah memutuskan pergi meninggalkan daerahnya. Hal ini terjadi karena di daerah asalnya masih terdapat faktor yang mengikat atau menahan mereka untuk tetap tinggal, seperti beratnya meninggalkan keluarga, adanya beban tanggung jawab terhadap pekerjaan, maupun peran sosial di daearh asalnya. Tarikan antara faktor di daerah asal dan daerah tujuan, akan membuat orang kemudian memilih jalan tengah dengan melakukan migrasi tidak permanen atau migrasi sirkuler. Hal ini karena walaupun mereka akan pergi dari daerahnya, namun hanya untuk beberapa hari saja dan tidak menetap di daerah tujuan, dan setelah selesai terapi pengobatan mereka akan kembali ke daerah asalnya. Hal ini akan berulang kembali karena tahap pengobatan penyakit kanker tidak berlangsung dalam satu kali terapi saja. Selain tersedianya fasilitas pelayanan kesehatan yang terdapat di daerah tujuan, keputusan untuk melakukan migrasi untuk pengobatan keluar daerah juga dapat dipengaruhi oleh orang lain, terutama oleh orang yang telah pernah tinggal di daerah tersebut, karena mereka merupakan orang yang mengetahui dan mengenal dengan lebih baik mengenai kondisi daerah tujuan (Mantra, 1985).

\section{Faktor yang Mempengaruhi Pilihan Daerah Tujuan}

Pada umumnya sebelum pasien kanker melakukan migrasi, mereka akan diberikan alternatif daerah tujuan untuk berobat oleh pihak dokter atau rumah sakit. Ada beberapa hal yang mempengaruhi seseorang dalam memilih daerah tujuan untuk melakukan pengobatan dan terapi terhadap penyakit yang dideritanya antara lain, jarak daerah atau 
tempat pengobatan, kondisi lingkungan daerah tujuan, dan informasi yang diterima seseorang mengenai daerah tujuan tersebut.

Jarak suatu daerah dengan daerah lain mempengaruhi dalam pengambilan keputusan untuk menentukan daerah mana yang dipilih sebagai daerah tempat pengobatan, sebagaimana Lee (2000) yang menyatakan jarak sebagai rintangan antara yang berpengaruh dalam pengambilan keputusan bermigrasi. Migran cenderung untuk memilih tempat terdekat sebagai daerah tujuan. Ravenstain (dalam Mantra, 1999) menyebutkan salah satu hukum migrasi bahwa orang cenderung memilih daerah tujuan yang dekat dengan tempat tinggalnya. Terlebih pada pasien yang kondisi fisiknya lebih lemah daripada orang sehat. Jarak yang tidak terlalu jauh dari daerah asal dan kondisi lingkungan yang dinilai nyaman oleh pasien membuat mereka memutuskan memilih daerah tertentu daripada daerah lain yang juga memiliki fasilitas kesehatan yang lengkap. Berikut pernyataan salah satu informan asal Purworejo:

"Saya tahunya di sini ada klinik khusus buat penyakit kanker ya setelah ngobrol dengan teman. Dia tahu informasinya dan dikasih tahu ke saya, nyarankan saya untuk ke Sardjito saja, ya sudah saya milih berobat ke sini saja, kan juga dekat dengan rumah, kalau mau nglaju juga gampang, pakai kereta (api) malah ngirit" (Ibu Kr)

Selain faktor jarak, penilaian pasien kanker terhadap daerah tujuan juga mempengaruhi pilihan kemana mereka akan melakukan migrasi. Penilaian ini dapat terjadi karena adanya pengaruh dari orang lain yang telah mempunyai pengetahuan tentang kondisi daerah tersebut. Seperti diungkap oleh $\mathrm{Ibu} \mathrm{Sr}$ dan ibu Wy yang memiih daerah tujuan setelah membuat penilaian terhadap kondisi lingkungan dan karakteristik penduduk daerah tujuan:

"Dulu saya dikasih pilihan sama pak dokter, (mau) ke Semarang, Yogya, atau Jakarta, Bandung, Surabaya. tapi saya sama bapaknya (suami) milihnya Yogya saja, kayaknya suasana kotanya lebih enak, tidak terlalu panas, dan nyaman. Kalau ke Jakarta males, karena kotanya ramai dan macet. Apalagi kan kalau buat orang sakit suasana macet malah bikin stres". (Ibu Sr)

Penilaian terhadap daerah tujuan dipengaruhi oleh informasi yang diterima oleh tiap individu. Informasi dapat diperoleh antara lain dari orang yang telah melakukan mobilitaas ke daerah tersebut. Informasi dari saudara maupun teman yang telah berpindah ke daearh tujuan merupakan hal yang penting terhadap pengambilan keputusan melakukan migrasi. Informasi yang sifatnya negatif atau kurang baik mengenai daerah tujuan tentu akan mengurangi minat seseorang menuju daerah tersebut. Demikian pula yang terjadi pada Ibu Wy, yang belum mengenal sama sekali dengan kondisi daerah tujuan, sehingga ketika dia diberikan pilihan rumah sakit untuk berobat, dia memilih berdasar innformasi yang diperoleh dari anggota keluarganya, berikut pernyataan ibu Wy:

"Kalau saya dulu disuruh milih mau berobat lanjutan, mau ke semarang apa mau ke yogya. Dokternya tidak menentukan, semua terserah pasien mau yang mana, nanti tinggal dibuatin rujukan. 
Nah, sama adik saya yang pernah kerja di Yogya menyarankan saya untuk (berobat) ke Yogya saja. Karena menurut dia, orang (masyarakat) Yogya kalau bicara itu halus dan kalem. Apalagi kalau kita lagi (dalam kondisi) sakit, kan kalau dengar orang bicara dengan nada yang halus akan enak di dengar. Sama-sama kalimat yang diucapkan, tapi kalau (nada) ngomongnya keras dan ketus kan akan beda rasanya dengan yang diucapkan dengan nada halus. Kalau saya sendiri malah tidak tahu mau milih yang mana, bingung milih mana, jadi ya saya ikuti saran adik saya" (Ibu Wy).

Jarak memang mempunyai pengaruh dalam pengambilan keputusan dalam melakukan migrasi untuk pengobatan, akan tetapi pada pasien kanker hal tersebut bukan menjadi hal utama atau faktor penentu untuk menentukan pilihan daerah tujuan untuk berobat. kondisi iklim atau cuaca daerah tersebut, kondisi lingkungan tempat tujuan, dan penilaian pasien terhadap kondisi atau karakter masyarakat daerah tujuan, yang semuanya tentu saja dipengaruhi oleh pengetahuan dari masing-masing pasien kanker terhadap suatu daerah.

\section{Penutup}

Proses pengambilan keputusan untuk melakukan migrasi sirkuler pada pasien, menuju Yogyakarta dalam rangka memenuhi kebutuhan kesehatan, tidak berlangsung dengan mudah. Terdapat beberapa faktor yang menjadi pertimbangan bagi pasien sebelum melakukan migrasi sirkuler tersebut, antara lain adalah, pertimbangan keluarga dan tanggung jawab pekerjaan yang ditinggalkan, keterbatasan fasilitas kesehatan di beberapa daerahnya, terutama terkait dengan terapi perawatan penyakit kanker. Keluarga menjadi bahan pertimbangan utama pasien, namun keluarga juga yang akan memberikan dukungan bagi pasien untuk melakukan migrasi demi pengobatan.

Selain itu diperolehnya informasi yang baik mengenai daerah tujuan mempengaruhi pasien dalam menentukan pilihan terhadap daerah yang akan dituju untuk melakukan terapi pengobatan. Informasi mengenai daerah tujuan diperoleh pasien dari anggota keluarga, teman, tetangga, rekan kerja yang memang telah mengenal kondisi lingkungan daerah tujuan. Informasi tersebut pada akhirnya akan mempengaruhi penilaian mereka terhadap daerah tujuan. 


\section{Daftar Pustaka}

Chyntia, Erlyn. 2009, Akhirnya Aku Sembuh dari Kanker Payudara; Semua Hal yang Harus Diketahui oleh Wanita Tentang Fakta dan Bahaya Kanker Payudara, Pencegahan, Deteksi Dini Serta Terapi Penyembuhan, Maximus, Yogyakarta

Jansen, Clifford. 1979, Beberapa A spek Sosiologis dari Migrasi, Pusat Penelitian Kependudukan UGM, Yogyakarta

Lee, Everett S. 2000, Teori Migrasi, Pusat Penelitian Kependudukan Universitas Gadjah Mada

Mantra, Ida Bagus. 1985, Pengantar Studi Demografi, Nur Cahaya, Yogyakarta. 1999, Migrasi Penduduk Sirkuler dari Desa ke Kota di Indonesia, Pusat Penelitian

Kependudukan UGM, Yogyakarta

Miles, Mathew dan Haberman, 1992, A nalisis Data Kualitatatif, UI Press, Jakarta

Muhidin, S. 2002, Estimasi Migrasi Penduduk, Pemanfaatan Data Sensus dan Supas, dalam Tukiran, dkk (ed), Migrasi Penduduk Indonesia, Tinjauan Lintas Disiplin, Pusat Studi Kependudukan dan Kebijakan, Universitas Gadjah Mada, Yogyakarta

Soebandri. 1996, Depresi dan Keganasan Kanker, Anima, Vol. XI No. 43

Taylor. R.C, 1969, Migration and Motivation, dalam Migration, Sociological Studies 2, J.A. Jackson (ed), Cambridge at University Press

Anita. 2000, http/www.geocities.com/anita_h_2000_girls/kankerpayudara

www.depkes.go.id, Kementrian Kesehatan Republik Indonesia, Kemenkes, Jika Tidak Dikendalikan 26 Juta Orang di Dunia Menderita Kanker,

http://www.ugm.ac.id/index.php?page=rilis\&artikel=1227, akses 20 Mei 2008, Pengukuhan Profesor Teguh Aryandono: Terapi Alternatif Memperlambat Terapi Medis Untuk Pengobatan Kanker Payudara. 